Archived version from NCDOCKS Institutional Repository http://libres.uncg.edu/ir/asu/

\title{
Appalachïan
}

B O O N E, N O R T H C A R O L I N A

\section{NUC, Quo Vadis? Have Mid-Size Academic Libraries Retained the National Union Catalog Pre-1956 Imprints?}

By: John P. Abbott \& Allan G. Scherlen

\begin{abstract}
Mid-size academic libraries face the dilemma of limited funding and space but are expected to provide the tools their graduate students and faculty need to compete in research. A question faced by these institutions is whether to weed potentially useful paper finding aids of the pre-online era. One example is the 754 volume National Union Catalog Pre-1956 Imprints (NUC). Has the content and current use of the NUC justified its retention by libraries in mid-size universities? The authors provide historical background of the NUC and the results of a survey of librarians from mid-size academic institutions that explores their perspectives on the tool's continued utility and their institutions' ultimate decisions on its fate.
\end{abstract}

Abbott, John, \& Scherlen, Allen. (2013). NUC, Quo Vadis? Have Mid-Size Academic Libraries Retained the National Union Catalog Pre-1956 Imprints?. Collection Management, 38(2), 119142. ISSN: 1545-2549, DOI:10.1080/01462679.2013.763740. Version of record available from Taylor \& Francis at http://www.tandfonline.com/ 
Abbott, J., \& Scherlen, A. (2013). NUC, Quo Vadis? Have Mid-Size Academic Libraries

Retained the National Union Catalog Pre-1956 Imprints?. Collection Management, 38(2), 119-

142. ISSN: 1545-2549, DOI:10.1080/01462679.2013.763740. Version of record available from

Taylor \& Francis at http://www.tandfonline.com/

\title{
NUC, Quo Vadis? Have Mid-Size Academic Libraries Retained the National Union Catalog Pre-1956 Imprints?
}

\author{
JOHN P. ABBOTT \& ALLAN G. SCHERLEN \\ Appalachian State University, Boone, North Carolina
}

Mid-size academic libraries face the dilemma of limited funding and space but are expected to provide the tools their graduate students and faculty need to compete in research. A question faced by these institutions is whether to weed potentially useful paper finding aids of the preonline era. One example is the 754 volume National Union Catalog Pre-1956 Imprints (NUC). Has the content and current use of the NUC justified its retention by libraries in mid-size universities? The authors provide historical background of the NUC and the results of a survey of librarians from mid-size academic institutions that explores their perspectives on the tool's continued utility and their institutions' ultimate decisions on its fate.

KEYWORDS: National Union Catalog, NUC, deselection, library space, library history

Address correspondence to John P. Abbott, Coordinator of Collection Management, Appalachian State University Libraries, 218 College Street, Boone, NC 28608. Email:

abbottjp@appstate.edu 


\section{INTRODUCTION}

Mid-size academic libraries face many challenging dilemmas unique to their class of academic library -- decisions larger Research 1 (R-1) institutions may not have to make. Defining a midsize academic library is inexact. For this study, mid-size academic libraries are characterized as those holding approximately 500,000 to 1,200,000 volumes; having a collections budget between US\$500,000 and \$5,000,000; and serving a student body of between 6,000 and 20,000. Midsized universities can be characterized using the Carnegie Foundation classification for Master's Large and Master Medium. These two classification categories encompass approximately onethird of universities when measured by the number of universities or by enrollment (Carnegie Foundation for the Advancement of Teaching, 2012). Mid-size academic libraries are generally funded at a much lower level than R-1 institutions. The authors' Master's Large university and its library are illustrative of the funding differences between mid-size and R-1 libraries: Appalachian State University's library materials expenditures are less than 25 percent of the averaged similar expenditures for the state's two public flagship R-1 libraries (Library Statistics Program 2010).

Mid-size libraries are not traditionally expected to hold the same comprehensive library resources as R-1 institutions, yet they are increasingly expected to hold --with limited funding and space -- the competitive level of research tools to permit their faculty and graduate students to succeed in their discipline. Simultaneously, changing patterns of library use have created demands for more study space, and these demands compete with collections space. Mid-size academic libraries must balance pressures for more comprehensive collections against their limited space and often unpredictable and usually declining funding for expansion. This quest for balance inevitably leads to questions about the retention of older, pre-digital paper finding aids: Are they worth keeping? And what do we do with those large bound index sets which are 
NUC, Quo Vadis?

increasingly superseded by newer online finding tools?

One such set is the monumental the National Union Catalog, Pre-1956 Imprints: A Cumulative Author List Representing Library of Congress Printed Cards and Titles Reported by Other American Libraries, referred to in most references and throughout this paper as simply the NUC (Library of Congress 1968). The full set of the National Union Catalog, Pre-1956

Imprints is 754 volumes, each $36 \mathrm{~cm}$. (14 in.) tall, with the set occupying almost 125 linear feet of oversized shelving. Hall (2004) indicates there were originally 1,350 subscribers in the US and abroad during its 14 years of production. A WorldCat search in August 2012, indicates more than 500 libraries currently show records for the $N U C$ in their catalogs Of those, 120 were determined to be held by members of the Association of Research Libraries (ARL). Many of the remainder are likely held by small and mid-size libraries.

The sheer size of the $N U C$ makes it relatively unique in mid-size academic libraries. There are few single-title paper sets other than law reporters and the United States Congressional Serial Set that occupy as much shelf space. Most of the large traditional sets have been digitized and are available online, usually for a fee, but the $N U C$ remains unavailable as a scanned document as of this writing. The HathiTrust appears to have digitized the $N U C$, but as of mid2012 the images are not yet available for viewing or searching upon online.

This paper begins by first reviewing the history of the $N U C$. It then reports on the results of the authors' survey of librarians in mid-size institutions. The study, central to this paper, seeks to determine these librarians' perceptions of current $N U C$ usage and factors that led to their institutions' decision to either retain or remove the $N U C$ from the collection. The responses are then compiled and the data and testimony compared and discussed. This survey is an examination of a fundamental library collections decision: whether to remove an old technology finding tool -- the 754 volume National Union Catalog Pre-1956 Imprints, which appears to 
NUC, Quo Vadis?

many contemporary librarians to be a superseded artifact of the pre-digital library before the Internet. How curious to see a wall of large format books containing prints of author-name library cards from books catalogued long ago at a limited number of major U.S. academic libraries. The broader goal of this article is to sample the best practices among libraries at midsize academic institutions not only for the $N U C$ decision, but also as an indicator to determine possible decisions on other remaining, pre-Internet, multi-volume, paper bound sets of library finding aids.

\section{History of the National Union Catalog Pre-1956 Imprints}

We can better appreciate why libraries are concerned with the retention of the National Union Catalog, Pre-1956 Imprints if we briefly review the project's amazing genesis and long history. In seeking out the beginnings of the $N U C$, a researcher may be disappointed by the lack of a single comprehensive monograph treatment. There are a number of entries in encyclopedias of library and information science, but these are brief treatments (Reitz 2004; Holley 2003; Smith 2003; Immroth 1976; Trezza 1993). The recently-issued Encyclopedia of Library and Information Science (Bates \& Maack 2010) lacks an entry for the NUC, though the set is mentioned in two other entries, including one on cataloging history.

One of the best published overviews of the project is in William Welsh's 1981 American Libraries article, "Last of the MONUMENTAL book catalogs," [the caps are Welsh's] written to celebrate the $N U C$ 's completion after fourteen years of work. Interestingly, Welsh predicts the set might be the last of its kind as "automation" was quickly being embraced by librarians.

Welsh traces the union catalog movement in the United States from 1901, when then Librarian of Congress, Herbert Putnam, announced his idea for a national union catalog on cards containing all the books of the major libraries in the U.S. The union catalog concept continued 
NUC, Quo Vadis?

forward with Rockefeller Foundation grants in the 1920s and 1930s (when over 6-million cards were added to the catalog), to the 1940 s with the publication of a 167 -volume book set of Library of Congress (LC) catalog cards, and then on through the 1950s when the book catalog production was separated into two parts, with 1955 and earlier (i.e., pre-1956) forming a "retrospective NUC." LC tracked 1956 and newer imprints in the quarterly, annual, and quinquennial issues of the current NUC. This effort continued until 1964, when the American Library Association and LC signed an agreement to pursue publishing in book form the pre-1956 NUC cards that had been produced by the pre-'56 NUC project (Welsh 1981).

The project undertaken was huge. Every week for fourteen years, twenty-five to thirty editors examined, corrected and made special additions to 20,000 author entry cards. These cards were then packed and flown every Friday on Pan Am flight 106 from Washington, D.C. to and the Mansell Publishing Company in London, England. The Mansell name appears on the spine of the $N U C$ volumes, and the set is often referred to as Mansell among librarians. The Mansell Publishing Company had established a good reputation by producing the catalog of the British Museum and had won the LC contract for the NUC. After each monthly printing, approximately five volumes of 600 to 700 pages each were mailed to subscribers. The total subscription cost for the entire 754-volume set, completed in 1981, was $\$ 35,000$ (Hall 2004; Janes 2008), and it was the largest single publication ever produced as of 1968 (Library of Congress 1968). In 2012 U.S. dollars, the cost would exceed $\$ 230,000$.

The NUC, Pre-1956 Imprints was the WorldCat and OCLC database of its time. Catalogers consulted it for authority; interlibrary loan (ILL) librarians used it to find library holdings from which to borrow; and researchers used the $N U C$ to locate works of an author that might otherwise elude them. But even as the final volumes of the NUC were completed in 1981, library automation was in rapid development. The Ohio University's Alden Library began 
NUC, Quo Vadis?

online cataloging in 1971, and by 1989 OCLC's Research Library Partnership had 100 members (OCLC 2012a; OCLC 2012b). These developments, particularly the newly-emerging OCLC system, did not render the $N U C$ obsolete. At that time, OCLC principally provided only current imprint records. Catalogers and ILL librarians in the 1980s continued to rely on the records in the National Union Catalog Pre-1956 Imprints to catalog or to locate older materials. Hsia (1980) writes that the Library of Congress had plans for a post-1955 paper successor to the NUC, but those ambitions were ultimately abandoned.

In their 2005 textbook, Evans and Saponaro make no mention of the NUC. Similarly, Johnson (2009) refers the NUC only in passing as an historical artifact in her foundational collection management text. The $N U C$ fares no better in contemporary cataloging textbooks, where it receives little or no mention. Chan's (2007) cataloging text does not mention it, nor do contemporary texts in authority work (Maxwell 2002; Taylor et al. 2004). The lack of treatment in library graduate school texts indicates that the $N U C$ receives little attention in contemporary collection development and cataloging and classification courses. If the $N U C$ is no longer important enough to teach in library education, then why are so many librarians reluctant to remove it? Are there still persuasive reasons for keeping it?

\section{A Key Issue: Space Problems in Academic Libraries}

Many mid-size academic libraries hold large bound sets of national union catalogs, including the book catalogs of the Bibliothèque Nationale de France and the Deutsche Nationalbibliothek. With the development of online bibliographic databases by the then Ohio College Library Center (OCLC), Research Library Information Network (RLIN), and Western Library Network (WLN), these paper finding tools became suspect of taking space that could be better utilized for more current materials or for patron seating. Troll (2002) observes that academic libraries have 
NUC, Quo Vadis?

steadily reduced or eliminated public and staff spaces in order to add growing physical collections. In the decade since Troll's study, this trend of reclaiming space for more physical collections appears to have slowed, and now collections space is being repurposed as public seating and study area, fitting the current trend of the library-as-place (Dew and Crumpton 2012; Robinson 2009). The demand for library space continues even with the advent of shelf-sparing ebooks. Finding adequate space is a concern for most mid-size and smaller academic libraries. Situ (2008) surveys 36 large North American academic libraries and reports 72 percent of the respondents had reached 70 percent or greater occupied shelf space; over 55 percent of the respondents had reached 80 percent or higher shelf capacity; and over 50 percent had reached "an acute space shortage."

The Welsh article contains interesting unique facts about the NUC Pre-1956 Imprints which dramatically illustrates its potential impact on space-related library issues: The 754 volumes of one set fill 125 linear feet of shelving. "Balanced one upon the other, the 13.6 inch volumes in a single set would be higher than the Pan Am Building in New York, though less suitable as a helicopter pad." $(1981,467)$. Is the NUC simply too large and too unused to justify its occupation of coveted library real estate? So, how much use does it get?

\section{Usefulness of the $N U C$}

First, it is important to understand what the $N U C$ is not. Evans notes in an earlier edition of his comprehensive collection development text that the "NUC is not a true national bibliography because its coverage is not comprehensive" $(2000,116)$. Its holdings information reflects a collection of cataloging cards from a subset of U.S. libraries, including the New York Public Library, The Boston Public Library, Harvard University Library, the University of Chicago's John Crerar Library, and several others (Welsh 1981). In a casual study, public librarian Danelle 
NUC, Quo Vadis?

Hall in American Libraries $(2004,80)$ compares a "very limited spot check" of NUC entries with WorldCat and found every title in WorldCat. Beall and Kafadar perform a more systematic study and argue "that a significant percentage (27.8\%) of the sample of records selected from the National Union Catalog Pre-56 Imprints are not represented by records in WorldCat" (2005, 434). In a follow-up to their study, DeZelar-Tiedman examines WorldCat holdings after the merger of RLIN records into OCLC's file and finds "the ability to access information about these materials, even in "old-fashioned" book catalogs, remains crucial...[because] a significant percentage of library materials, especially those that are old and rare, are not represented online in library catalogs" $(2008,405)$.

Anecdotal testimony of the $N U C$ 's potential usefulness can be found in a 2004 online archive of COLLDV-L, an e-mail discussion group for collection development librarians, where participants vary in their responses regarding the $N U C$ s usefulness. One list member shares findings of an informal sampling of ten searches for $N U C$ items in WorldCat, discovering two NUC titles that are not found in the digital database. At least anecdotally, some librarians responding still consider the $N U C$ to be a valuable tool for occasional tasks in cataloging or browsing for author names when the exact spelling is not known. Other list members express its usefulness in finding the first published item by an author or earlier editions and other retrospective examination of an author's works (COLLDV-L 2004). The authors, to date, can find no previously published studies that evaluate the usefulness of the $N U C$ focused specifically within mid-size university libraries.

\section{The $N U C$ at Appalachian State University}

The authors recall an incident in the late 1990s at Appalachian State University that brings light to the issue of the NUC. "What are those giant green books?" asked a bright, newly-hired 
NUC, Quo Vadis?

librarian standing near the wall of National Union Catalog Pre-1956 Imprints in the far back of the reference collection. Before the question could be answered, a volume was pulled down revealing the curious sight of page after page of photographed author catalog cards.

Recent generations of librarians, as noted earlier, have emerged from their ALAaccredited graduate programs knowing little about the history or utility of the $N U C$. An informal inquiry by the authors of some recently-degreed librarians at their institution indicates that none of them know about the $N U C$. This should not be surprising given the lack of treatment in current collection management and cataloging textbooks (Maxwell 2002; Taylor et al. 2004; Chan 2007; Johnson 2009). But the NUC has become an object of curiosity and occasional discussion among collection management librarians at Appalachian State. Most recently, the set gained its greatest attention prior to Appalachian State library's move to a new building in 2005.

In the new building, the reference collection was to be greatly reduced in size by retaining only the most essential reference items and slating the rest for either discard or transfer to other areas of the library. Many large sets such as Biological Abstracts, PAIS and other multivolume indexes that were being superseded by online resources--but not yet ready to be pitched-were marked for integrating into the main collection of the new library. $N U C$, originally shelved in Reference, had the same fate: first to the end of the Zs in main circulating stacks and then, a few years later, transferred down to periodical compact shelving as space from weeded paper journals became available.

In the intervening seven years since the move, most of the print abstract and index bound volumes have been discarded. Librarians, like their users, have come to accept dependence upon e-resources, and are comfortable even with the potential consequences of inaccessibility through technical malfunction, shutting down of the database by the providing company, or local budgetary downturns. Or as a librarian commented to the authors: "If all our library database 
NUC, Quo Vadis?

subscriptions were cancelled, students would still not use our paper indexes. They would get what they could through Google and other sources online or drive to another library that still had database access.”

The $N U C$ was one set the librarians of Appalachian State were not so sure about in 2005 or now. It was large and enigmatic. Some of the staff knew of it or had done class exercises with it in library graduate school. All of Appalachian State's librarians who had lived through the fourteen years of its subscription from 1968 to 1981 had since retired. Most of the current librarians now regard the $N U C$ much as hominids regarded the huge black monolith seen in the film 2001: A Space Odyssey: mysterious, from another time, and of uncertain power and utility (Kubrick 1968).

To gain the perspective of librarians who had used the $N U C$, two retired Appalachian State technical services librarians where separately interviewed by telephone by Allan Scherlen on June 12, 2012. John Heaton, a technical services librarian at Appalachian State from 1969 to the mid-nineties, recalled that the catalog librarians were adamant that the $N U C$ was needed for cataloging and a subscription was begun early in his tenure in the late 1960s. Lynne Lysiak, who was instrumental in bringing access to OCLC automated cataloging to Appalachian State and many other universities in the Southeastern U.S. in the 1970s and 1980s, explained that the NUC was needed to accomplish cataloging and interlibrary loan work during those decades: "OCLC only loaded records for current books. You still needed the $N U C$ and other sources for authority work. It was essential for cataloging and interlibrary loan." She also noted that faculty in the English Department required graduate students in their bibliography classes to use the $N U C$ and other national book catalogs such as that of the British Museum to explore various editions of works; "Sometimes the catalogers complained they couldn't get to the volume of the NUC they needed because of all the graduate students using it." 
NUC, Quo Vadis?

Librarians now rely on multiple online bibliographic resources. Most have forgotten or never knew that in the recent past -- within the memory of some librarians still in practice -librarians were dependent on paper resources such as the $N U C$ for the success of good library work in cataloging, ILL, or reference. But what is the importance of tools like the NUC today? Larger research libraries will likely continue to hold the $N U C$ and indeed have occasions to use it for acquired older materials or exhaustive bibliographic surveys. But librarians at mid-size universities, such as Appalachian State, face the inescapable question: Is it still necessary for a mid-size academic library to hold the 754 large volumes of the $N U C$ and allocate the space for it? To find an answer to this question, the authors set out to survey librarians in similar circumstances to understand if they have retained or discarded their $N U C$ set and why. Are there convincing reasons for keeping or discarding this grand old set?

\section{THE MID-SIZE ACADEMIC UNIVERSITY LIBRARY STUDY}

During May 2012, a web-based survey was used to gather data for a qualitative study of libraries at mid-size universities in the United States. The libraries surveyed were most often institutions classified by the Carnegie Foundation as Master's Larger and Master's Medium institutions. These are defined as institutions awarding at least 50 master's degrees and fewer than 20 doctoral degrees annually (Carnegie Foundation for the Advancement of Teaching 2012). A call for respondents was sent to a collection development discussion listserv, COLLDV-L, and also emailed directly to heads of collection development and heads of cataloging in 121 libraries identified as Appalachian State's peer or peers of peer institutions. A link to the survey was provided with a short explanation of the survey and who the target respondents were. Sixty-two useable completed surveys consisting of 29 questions were gathered using a SurveyMonkey instrument (www.surveymonkey.com) (Appendix A). Respondents supplied basic institutional 
NUC, Quo Vadis?

data, but remained anonymous. A response was required for each question and participants were able to add comments to many of the questions.

\section{METHODOLOGY AND RESULTS}

\section{Part 1 of the Survey: Institutional Data}

All respondents provided institutional information which was used to characterize the responding libraries. The information included an inquiry about the presence of the $N U C$ at their institution - whether their library currently or in the past had a set. The respondents were asked about their job responsibilities because such information might show differences in attitude toward the $N U C$ between catalogers and collection managers. They were also asked about the size of their university, size of the library's materials budget, and their library's physical space concerns. Finally, in the institutional information portion of the survey, the respondents were asked about their library’s practices for collecting monographs published before 1956, and for collecting books in languages other than English that presumably might only be found in the $N U C$. Each of those measures is summarized below.

\section{1a. Respondents' Ownership of the NUC}

The survey was completed by 62 respondents. The majority of respondents indicate their libraries hold the full set of the NUC (73 percent, $\mathrm{n}=45)$. A smaller number of respondents report their libraries (21 percent, $\mathrm{n}=13$ ) had once held the $N U C$ and chose to discard it. One library holds an incomplete $N U C$ set and three respondents' libraries have never owned the $N U C$. The response for the incomplete set is pooled with the full set responses. The respondents who have never acquired the $N U C$ were discarded from the study. The responses holding the 
NUC, Quo Vadis?

$N U C(\mathrm{n}=46)$ are compared with those discarding $(\mathrm{n}=13)$ for commonalities and differences that might indicate why some retain the $N U C$, while others chose to withdraw it from the collection. Differences within the Holding and Discarding groups are also examined.

\section{1b. University and Materials Budget Size}

The majority of the Holding respondents (70 percent) are in universities larger than 10,000 FTE. The majority of Discarding respondents (62 percent) report FTE's fewer than 10,000 FTE. Interestingly, the materials budgets at Holding respondents' libraries span the full question range of less than US\$500,000 to more than US\$5 million, while Discarding respondents' report no collections budget less than US\$ 500,000 and none greater than US\$ 5 million. In both groups, the budget median is between US\$1MM and \$3MM. Therefore, among the respondent population, Holding libraries tend to have larger student populations, but defining differences in materials budgets are less clear.

\section{1c. Perceptions of Shelf Space Availability}

Respondents holding the $N U C$ report fewer concerns about library space. Among the Holding respondents, almost three-fourths (72 percent) report their library has sufficient current space. Only 17 percent of Holding respondents indicate shelf space is a current issue, with another 10 percent indicating shelves are nearing full. Among Discarding libraries, almost half (46 percent) of respondents state limited shelf space is a current issue, and 15 percent report that shelves are nearing full. Holding library respondents, therefore, are less likely than Discarding library respondents to have shelf space concerns.

\section{1d. Acquisitions in a Language Other than English}


NUC, Quo Vadis?

All respondents indicate that non-English acquisitions are only a small part of their overall annual acquisitions. Two-thirds of Holding respondents (67 percent) report that non-English acquisitions comprise less than five percent annual accessions. For Discarding respondents, 92 percent report non-English is less than five percent of all annual acquisitions. In both groups, acquisitions in languages other than English are a very minor part of purchases or gifts. Cataloging of non-English pre-56 imprints - a potential use of the NUC suggested by discussion list comments - does not appear to be a large need of either group in this study's respondents.

\section{1e. Annual Acquisition of Pre-1956 imprints}

All survey respondents indicate that pre-1956 imprints, books published before 1956, are only a small portion of annual acquisitions via gifts or purchases. Among Holding respondents, 82 percent estimate five or fewer percent of annual accessions are pre-1956 imprints. Among Discarding libraries, 100 percent of respondents report adding no pre-1956 monographic materials. In both groups, current monographic acquisitions are rarely older than the mid- $20^{\text {th }}$ century. The $N U C^{\prime}$ 's utility in cataloging pre-56 imprints appears rarely needed in either group.

\section{1f. Remarks about Part 1 of the Survey}

Survey institutional data indicate that a strong delineator between Holding and Discarding respondents appears to be the size of the student FTE population, with Holding institutions generally serving student populations of 10,000 FTE or larger and Discarding libraries having student populations smaller than 10,000 FTE. The annual materials budget is not a good delineator of retention or withdrawal decisions for the $N U C$. Holding library respondents express fewer shelving space concerns. Both groups acquire very few non-English or pre-1956 monographs. 


\section{Part 2 of the Survey: Housing and Use of NUC}

The second section of the survey asked respondents in the Holding libraries to describe where they shelve the $N U C$ and to indicate for what purposes the $N U C$ is used. Respondents of Discarding libraries were asked about the discard process for the $N U C$.

\section{2a. Holding Libraries: Where is the NUC Housed?}

Holding library respondents note a variety of locations for the housing of the NUC sets (Table 1).

Locations accessible to the public dominate the responses (76 percent) and include the main open stacks, regular and compact; open and compact reference stacks; government documents; and special collections. Two respondents indicate that the public area placement of the $N U C$ is decorative and used as barrier walls to define study space areas or to fill lower, unused shelves in an information commons area. Sixteen percent indicate that they house the set in the technical services area. Three respondents (6 percent) note that they keep the set in remote storage; one stores it in an automated retrieval system.

Table 1 Location of the $N U C$ in Library

\begin{tabular}{|l|c|c|}
\hline \multicolumn{1}{|c|}{ Location } & \% & N \\
\hline Special Collections & $8 \%$ & 4 \\
\hline Remote storage & $6 \%$ & 3 \\
\hline Technical Services & $16 \%$ & 8 \\
\hline Print Reference collection area & $16 \%$ & 8 \\
\hline Main stacks & $22 \%$ & 11 \\
\hline Other location in the public area & $35 \%$ & 17 \\
\hline
\end{tabular}

2b. Holding Libraries: Who are the Users of the $N U C$ ? 
NUC, Quo Vadis?

Respondents were asked to select known users from several categories of potential users.

Undergraduate students are the smallest group, with only a single library reporting knowing of use of the NUC by these students (Table 2). The greatest use is by library workers, with comments referring to catalogers and ILL staff. One comment describes "Other" users as faculty from nearby institutions. One-third of respondents (the third largest group) answer they do not know who uses the NUC. Of eleven text comments, seven report no known uses of the set and one comments, "We're keeping it around for sentimental reasons."

Table 2 Users of the $N U C$

\begin{tabular}{|l|c|c|}
\hline User Category & \% & N \\
\hline Undergraduate students & $2 \%$ & 1 \\
\hline Graduate students & $12 \%$ & 6 \\
\hline Community/Other & $14 \%$ & 7 \\
\hline Research or teaching faculty & $37 \%$ & 18 \\
\hline Library faculty or staff & $57 \%$ & 26 \\
\hline Do not know & $33 \%$ & 16 \\
\hline
\end{tabular}

\section{2c. Holding Libraries: Is the NUC Used for Class Assignments?}

The survey asked if respondents were aware of class assignments requiring the $N U C$ and 89 percent knew of no assignments. Those who are aware of $N U C$-related assignments report required use by English, history, and library science students, presumably at the graduate level. When asked to estimate how often the $N U C$ is used by patrons in a year, "Never", leads the list at 41 percent, with zero to five uses following at 31 percent (Table 3 ).

\section{2d. Holding Libraries: How Often is the NUC Used?}


NUC, Quo Vadis?

When respondents were asked when they as librarians or researchers last used the $N U C$, one-fifth indicate within the past year, a second fifth used it in the last 1 to 5 years, and approximately half have not used it in five years. Respondents with cataloging responsibilities are slightly more than twice as likely to have used the $N U C$ in the most current year as those with primarily collection development responsibilities ( 25 vs. 11 percent). None of the responding cataloging librarians selected the survey choice of "Never" having used the $N U C$.

Table 3 Estimated Amount of Annual Use of the NUC

\begin{tabular}{|l|c|c|}
\hline Frequency & \% & N \\
\hline $20+$ & $6 \%$ & 3 \\
\hline 6 to 20 & $10 \%$ & 5 \\
\hline 0 to 5 & $31 \%$ & 15 \\
\hline Never & $41 \%$ & 20 \\
\hline Do not know & $13 \%$ & 6 \\
\hline
\end{tabular}

\section{2e. Holding Libraries: Keeping the Beast}

A somewhat whimsical question posed to Holding respondents asked, "If you could wave a magic wand and have the NUC disappear without a trace or a memory, would you?" Unexpectedly, approximately equal percentages (28 and 30 percent respectively) of those with primary responsibilities in collections and cataloging reply "Yes" to having the NUC disappear. This outcome is countered by half of collection development and two-thirds of cataloging respondents answering "No". Nearly three-fourths of those with blended responsibilities, often including management across units, also indicate "No". Comments related to their response to a magical disappearance of the NUC are (1) its immense bulk precludes an easy method for disposal; (2) the importance of the NUC as history; (3) the lack of an available digitized version; (4) concerns about $N U C$ content not available in WorldCat; and (5) significant reclaimed space 
NUC, Quo Vadis?

from the removal of print duplicates of digital journal volumes makes weeding the $N U C$ a lower priority. Therefore, some libraries feel no urgency to withdraw the $N U C$ even though their statistics indicate little if any use in the past 10+ years;

Twenty percent of collections respondents versus five percent of catalogers are "indifferent" to the magical disappearance. Overall, catalogers are most opposed to having the $N U C$ disappear (65 percent) while collection managers are split: half of collections respondents are opposed to having the $N U C$ disappear (50 percent) and the other half is further split between indifference (22 percent) and willingness to have it disappear (28 percent). Catalogers, interestingly, have far less indifference ( 5 percent), indicating perhaps a greater self-assuredness than collection managers about the set's current utility or lack thereof (Table 4).

Table 4 "If you could wave a magic wand and have the $N U C$ disappear without a trace or a memory, would you?"

\begin{tabular}{|l|c|c|c|}
\hline Primary Responsibility & Yes & No & Indifferent \\
\hline Cataloging & $30 \%$ & $65 \%$ & $5 \%$ \\
\hline Collection Development & $28 \%$ & $50 \%$ & $22 \%$ \\
\hline Other & $9 \%$ & $73 \%$ & $18 \%$ \\
\hline Overall & $25 \%$ & $61 \%$ & $14 \%$ \\
\hline
\end{tabular}

\section{2f. Holding Libraries: Why has the NUC Been Retained?}

If the decision was made by a Holding library to retain the $N U C$, then why do respondents think the NUC was kept? The reasons stretch across the board (Table 5) with the most common reasons being (1) concern for loss of content that is not included in WorldCat; (2) more cogent organization of the $N U C$ versus WorldCat; and (3) continued usefulness of the NUC to researchers. These reasons are followed by arguments for the set's iconic status (more of a concern to collection development than other groups) and possible unrecognized use by 
NUC, Quo Vadis?

occasional unrecorded perusers. Interestingly, the possible negative public relations effects of weeding are of concern to only 13 percent of respondents. Finally, two respondents cite the decorative quality of the set in the library as a reason for keeping it.

Table 5 Rationale for Keeping the $N U C$

\begin{tabular}{|l|c|c|}
\hline \multicolumn{1}{|c|}{ Rationale } & \% & N \\
\hline Public relations concerns / Patron backlash & $12 \%$ & 6 \\
\hline The high cost of physical removal (labor, recycling, etc.) & $14 \%$ & 7 \\
\hline Difficulty in finding our set a new home & $14 \%$ & 7 \\
\hline There may be NUC users we are unaware of & $29 \%$ & 14 \\
\hline It was an expensive and iconic work & $33 \%$ & 16 \\
\hline Still of use to researchers & $49 \%$ & 24 \\
\hline Still useful for cataloging or ILL, not all content is in Worldcat & $53 \%$ & 26 \\
\hline
\end{tabular}

Note: Percentages add to more than 100\% because respondents were able to select all options that applied.

\section{2g. Holding Libraries: Remarks About Part 2 of the Survey}

In summary, respondents from Holding libraries report housing the $N U C$ most often in a public location; indicate the largest user group is library staff, followed by researchers in the disciplines of English, history, and library science. One-third of Holding libraries expect fewer than five uses per year and 40 percent expect no use during the year. All Holding libraries expect essentially no undergraduate use and all choose to retain the set because of advantages or content the $N U C$ has over the WorldCat and the set's possible use to researchers.

Part 3 of the Survey: Respondents in Libraries that Withdrew the NUC

The Discarding library respondents, those having withdrawn the $N U C$, comprise approximately a quarter $(n=13)$ of all completed survey responses. These respondents, overall, tend to be located in smaller universities with smaller student FTE enrollment $(<10,000$ FTE). Two-thirds 
NUC, Quo Vadis?

describe their library's shelf space situation as "concerning" to nearing full. For most (92 percent), non-English acquisitions account for less than five percent of the annual monograph purchases, and 100 percent report that imprints prior to 1956 comprise less than five percent of monographic acquisitions.

\section{3a. Discarding Libraries: When was the NUC Removed and What was its Fate?}

Most Discarding respondents indicate the decision to remove the $N U C$ was made in recent years, with almost two-thirds reporting removal in the last five years (Table 6). More than half of the respondents (54 percent) report having recycled the 754 volumes. Other after-discard outcomes include: (1) transferring to consortial storage; (2) sending to state or university surplus; (3) giving to another library; or, as one comments, (4) deaccessioning along with “...old law collection materials to build group areas for students to study. They are very popular. The books were placed on shelving units that make up a box...a room so-to-speak."

Table 6 Removal Date of the NUC

\begin{tabular}{|l|c|c|}
\hline \multicolumn{1}{|c|}{ Years Ago } & \% & n \\
\hline 6 to 10 years ago & $15 \%$ & 2 \\
\hline $11+$ years ago & $23 \%$ & 3 \\
\hline 0 to 5 years ago & $62 \%$ & 8 \\
\hline
\end{tabular}

\section{3b. Discarding Libraries: Why was the NUC Deaccessioned and Who Decided?}

Eleven of the thirteen Discarding respondents (85 percent) indicate that their library removed the $N U C$ because of lack of use. The second most common reason is the need for space (62 percent). One library mentions that their knowledge of two other copies of the $N U C$ in their consortium justified removal. 
NUC, Quo Vadis?

Overwhelmingly, librarians drive the decision to remove the $N U C$; ninety-two percent of the respondents indicate it was a library decision. Only eight percent of the $N U C$ weeding processes included teaching or research faculty. Approximately one-quarter of the responding libraries consult other libraries about the decision.

3c. Discarding Libraries: Reactions, Regrets, and Moving on after the Removal of the $N U C$

All Discarding respondents $(n=13)$ provide comments about reactions to the removal of the NUC. The most common comment is that there was No reaction after removal of the NUC (69 percent). Among these comments one indicates that they had anticipated negative reactions from teaching faculty, but none materialized. Three respondents ( 25 percent) report later feelings of unhappiness among interlibrary loan or cataloging staff as a result of the withdrawal. When asked if there are regrets after weeding the $N U C, 85$ percent have no regrets. The respondent comments can be summarized as: (1) they could have removed it sooner; (2) the $N U C$ is available in a nearby library when needed; (3) since the $N U C$ removal all acquisitions printed before 1956 are found in WorldCat; (4) though the $N U C$ was expensive, it paid for itself over the years, and is no longer useful; and (5) the most unique observation is, "It still feels a little like having put a beloved elderly pet to sleep, but it was the right decision for us."

How do Discarding library respondents cope without the $N U C$ at hand? More than threefourths report using original cataloging (77 percent). One comment indicates that needed volumes for cataloging are borrowed by interlibrary loan when needed. One cataloging respondent from a school of 10 to 20 thousand FTE observed it is their “...professional opinion that if a book is in $N U C$, but not in OCLC then perhaps there are no extant copies." 
NUC, Quo Vadis?

\section{3d. Discarding Libraries: Remarks about Part 3 of the Survey}

In summary, most respondents who weeded the $N U C$ report removing it within the last five years. More than half chose to discard the volumes, while others sent the $N U C$ to surplus, consortial storage, or another library, or kept it in the building to use it for decoration or constructing study space. Discard decisions are driven and controlled by librarians and most have neither regrets nor encounter any significant adverse consequences from withdrawal of the set.

\section{DISCUSSION AND CONCLUSION}

In this survey, librarian respondents in mid-size universities indicate most of their libraries have retained The National Union Catalog, Pre-1956 Imprints. An analysis of these decisions indicates: (1) Retention is apparently not based on significant use of the set; seventy percent indicate the set is consulted 0 to 5 times per year across the 754 volumes. (2) Retention is apparently not based on vital collection management or cataloging needs either, as most responding libraries report few annual collection additions of pre-1956 imprints. But, interestingly, cataloging librarians are much more inclined to keep the set than collection development librarians. And finally, (3) retention does not seem to be based on possible public relations dilemmas since only 13 percent were concerned with patron backlash if the $N U C$ were to be discarded. Importantly, among respondents reporting removal of the $N U C$, almost all have no regrets about the decision.

The authors weighed the findings of this study in deciding the fate of their own set of $N U C$ volumes. A positive benefit of retaining the set is having access to the fraction of records in the $N U C$ that are not present in WorldCat. Other deaccessions in the library have relieved the pressure to repurpose the stacks space currently occupied by the NUC. Other more urgent 
NUC, Quo Vadis?

projects demanding staff and student worker time also mitigate against discarding the huge amount of physical material at the present time. Lastly, our local discussions of the $N U C$ prompted a faculty member to come forward requesting we retain the set. Like many of the respondents of this study, the authors have chosen to take the careful road for the time being and postpone discarding their $N U C$ for another year.

However the generation of librarians who actively used the $N U C$ in the past is rapidly passing from the scene. Also leaving the academy are the library science and other academic teaching faculty who used the $N U C$ in research and teaching. For mid-size academic libraries, the role of tools such as the $N U C$ is ambiguous when compared to the research and library-ofrecord missions of large, well-funded R-1 research libraries. Mid-size academic libraries are charged to support faculty and students with adequate research tools, but with much less funding and space. These limitations translate into difficult weeding decisions, especially regarding massive and rarely used bound sets, such as the $N U C$, as this study illustrates.

The story of the NUC Pre-1956 Imprints is a fascinating part of twentieth century library history, central to the story of libraries' transition from the analog to digital. It represented a monolithic achievement in the ongoing quest by libraries to streamline access to the world's literature. As Joseph Janes $(2008,34)$ simply notes, the $N U C$ is "an example of the creativity and hard work of librarians." Perhaps the next decision point for mid-size academic libraries unable or unwilling to discard the $N U C$, will occur when the HathiTrust, Google, or other digitizer announces the release of a searchable digital version of the work.

The $N U C$ may be part of a paradigm in librarianship that "nothing is perfect, nothing lasts, and nothing is finished" (Powell 2006, 98). The NUC may be one of the most obvious and iconic constructions, but within the 14 years following its completion (the same length of time to complete the set), the $N U C$ 's continued utility was being superseded by the rapidly-expanding 
NUC, Quo Vadis?

online databases of OCLC and other bibliographic services. Other time-honored but nearobsolete library tools, such as the many shelves of niche subject bibliographies, bound library catalogs of Europe, and the Cumulative Book Index (CBI) await a similar examination in midsize academic libraries. Further demand for space and the passing of the last users will likely speed the removal of the $N U C$ and other traditional reference tools even if these decisions can be unexpectedly difficult — especially since we do not always retain these tools for altogether logical reasons. Author and poet Gurney Norman (2001) put it well when he said, "Iconic figures confuse things more than they illuminate things." The retention of the NUC and its iconic status among librarians illustrate this dilemma.

\section{REFERENCES}

Bates, Marcia J., and Mary Niles Maack. 2010. Encyclopedia of Library and Information Sciences. Boca Raton, FL: CRC Press.

Beall, Jeffrey, and Karen Kafadar. 2005. "The Proportion of NUC Pre-56 Titles Represented in OCLC WorldCat.” College \& Research Libraries 66 (5): 431-435.

Carnegie Foundation for the Advancement of Teaching. 2102. "Classification Descriptions." http://classifications.carnegiefoundation.org/descriptions/ (Accessed November 28, 2012).

COLLDV-L. 2004. "CDL: Keeping the NUC, aka Mansell, pre-56?” COLLDV-L Archives, February-April 2004, available at http://serials.infomotions.com/colldv-1/

Chan, Lois Mai. 2007. Cataloging and Classification: An Introduction. 3rd ed. Lanham, Md: Scarecrow Press. 
NUC, Quo Vadis?

Dew, Stephen and Michael Crumpton, 2012. "Taking A Step Back, To Move Forward”. In Proceedings of the Charleston Library Conference, 2010: Anything goes, edited by Katina Strauch et al., 77-80. West Lafayette, IN: Perdue University Press.

DeZelar-Tiedman, Christine. 2008. "The Proportion of NUC Pre-56 Titles Represented in the RLIN and OCLC Databases Compared: A Follow-up to the Beall/Kafadar Study.” College \& Research Libraries 69 (5): 401-406.

Evans, G. Edward. 2000. Developing Library and Information Center Collections. 4th ed. Englewood, Colo: Libraries Unlimited.

Evans, G. Edward, and Margaret Z. Saponaro. 2005. Developing Library and Information Center Collections. 5th ed. Englewood, Colo: Libraries Unlimited.

Smith, Inese. 2003. “Union Catalogues.” In International Encyclopedia of Information and Library Science. Edited by John Feather and Paul Sturges. $2^{\text {nd }}$ ed., 643. London: Routledge.

Hall, Danelle. 2004. “Mansell Revisited.” American Libraries 35 (4): 78-80.

Holley, Robert P. 2003. “Cooperative Collection Development.” In Encyclopedia of Library and Information Science $2^{\text {nd }}$ ed., Edited by Miriam Drake, 700. New York: Marcel Dekker. Hsia, Gloria. 1980. "Everything You Wanted to Know About the National Union Catalog but Were Afraid to Ask." MELA Notes 19, (February 1): 10-13. http://www.jstor.org/stable/29785090

Immroth, John P. 1976. "National Union Catalog." In Encyclopedia of Library and Information Science, ed. Allen Kent, 182-186. New York, Marcel Dekker.

Janes, Joseph. 2008. "Worth the Effort." American Libraries 39 (1/2): 34.

Johnson, Peggy. 2009. Fundamentals of Collection Development \& Management 2nd ed. Chicago: American Library Association. 
NUC, Quo Vadis?

Clarke, Arthur C. 1968. 2001, A Space Odyssey. Directed by Stanley Kubrick. New York: MGM/United Artists. 35mm film.

Library of Congress, American Library Association and National Union Catalog Subcommittee. 1968. The National Union Catalog, Pre-1956 Imprints; a Cumulative Author List Representing Library of Congress Printed Cards and Titles Reported by Other American Libraries. London: Mansell.

"Library Statistics Program: Academic Libraries.” 2010. National Center for Education Statistics accessed November 29, 2012, http://nces.ed.gov/surveys/libraries/academic.asp.

Maxwell, Robert L. 2002. Maxwell's Guide to Authority Work. Chicago: American Library Association.

Norman, Gurney. 2001. “Gurney Norman: A conversation.” By Guy Mendes. Living by Words, KET. http://www.ket.org/livingbywords/authors/norman_interview1.htm.

OCLC. 2012a. "In the Beginning...," accessed June 14, 2012, http://www.oclc.org/about/history/beginning.htm.

—. 2012b. "Story of the OCLC Research Library Partnership," accessed June 14, 2012, http://www.oclc.org/research/partnership/history.htm.

Powell, Richard. 2006. Wabi Sabi For Writers: Find Inspiration. Respect Imperfection. Create Peerless Beauty. Avon, MA: Adams Media.

Reitz, Joan M. 2004. Dictionary for Library and Information Science, 476. Westport, Conn.: Libraries Unlimited.

Robinson, Cynthia K. 2009. "Library Space in the Digital Age: The Pressure Is On.” The Bottom Line: Managing Library Finances 22 (1): 5-8.

Situ, Ping. 2008. "New Concept of Collection Management: A Survey of Library-Space Related Issues.” Journal of East Asian Libraries 144: 1-15. 
NUC, Quo Vadis?

Taylor, Arlene G., et al. 2004. Authority Control in Organizing and Accessing Information: definition and international experience. Binghamton, NY: Haworth Information Press.

Trezza, Alphonse F. 1993. "Library Cooperative Systems.” In World Encyclopedia of Library and Information Services 3rd ed. ed. Robert Wedgeworth. 482. Chicago: American Library Association.

Troll, Denise. 2002. "How and Why Libraries are Changing: What We Know and What We Need to Know." portal: Libraries and the Academy 2 (1): 99-123.

Welsh, William J. 1981. "Last of the MONUMENTAL Book Catalogs.” American Libraries 12 (8): 464-468. 
NUC, Quo Vadis?

\title{
Appendix A
}

\section{The Survey: Use and Retention of the National Union Catalog, pre-'56 [administered via SurveyMonkey: http://www.surveymonkey.com]}

\author{
Dear Library Colleague,
}

This survey takes less than 10 minutes. It collects data from midsized academic libraries about their ownership, use, and retention of the 754 volume National Union Catalog, pre'56 (aka Mansell). As you now, the NUC occupies approximately 150 linear feet of shelving and presents several cost/benefit, preservation, and utility questions. The set was a monumental project taking more than a decade to complete and has iconic status in libraries. We are attempting to assess the perceived utility of the set in mid-size academic libraries and are seeking your responses as department heads. Please feel free to consult with your staff if needed.

We hope to publish the results in the professional library literature in the next year. Thanks for your time and replies,

John Abbott \& Allan Scherlen

Appalachian State University Boone, NC

Questions? Please contact John Abbott : AbbottJP@appstate.edu

1. Your library (select one):

$\square$ has the full set of the $N U C$ in its collection.

$\square$ has an incomplete set of the NUC.

$\square$ had the $N U C$ and has withdrawn it.

$\square$ never owned the $N U C$.

Do not know.

\section{Libraries with $N U C$ in their collection.}

2. Your primary responsibility is:

$\square$ collection development.

$\square$ cataloging.

$\square \quad$ Other (please comment)

3. The approximate size of your institution's student FTE enrollment is (select one):

$\square \quad$ Under 6,000 FTE

$\square \quad 6,000$ to $10,000 \mathrm{FTE}$

$\square \quad 10,000$ to 20,000 FTE

$\square$ more than $20,000 \mathrm{FTE}$

4. Size of your annual collections budget for fiscal year 2010/2011 (select one):
$\square$ less than $\$ 500,000$
$\square \$ 500,000$ to $\$ 1$ million
$\square \quad \$ 1$ million to $\$ 3$ million
$\square \quad \$ 3$ million to $\$ 5$ million
$\square$ more than $\$ 5$ million 
NUC, Quo Vadis?

5. Subjectively, how do you describe your library's space situation for the paper collection? (select one)

$\square$ Adequate amount of shelf space for the foreseeable future.

$\square$ Still sufficient shelf space, but concerns for the future.

$\square$ Shelf space is a current concern.

$\square \quad$ Shelves are nearing full.

6. What is your estimate of your library's annual monograph acquisitions in a language other than English? (select one)

$\square$ less than $5 \%$

$\square \quad 5$ to $10 \%$

$\square \quad 10$ to $20 \%$

$\square$ more than $20 \%$

$\square$ Cannot estimate

7. What is your estimate of the percentage of titles, published prior to 1956, that you add annually? (select one)

$\square \quad 05$ percent.

$\square \quad 510$ percent.

$\square \quad 10$ to 25 percent.

$\square$ more than 25 percent.

$\square$ Cannot estimate

8. Where is the $N U C$ housed in your library? (select all that apply)

$\square$ Print Reference collection area.

$\square \quad$ Main stacks.

$\square$ Technical Services.

$\square$ Special Collections.

$\square$ Remote storage.

$\square$ Other location in the public area.

Other (please comment)

9. Known users of the $N U C$ are (select all that apply):

$\square$ Library faculty or staff.

$\square$ Research or teaching faculty.

$\square$ Undergraduate students.

$\square$ Graduate students.

$\square$ Community users.

$\square$ Do not know.

Other. Other (please comment)

10. Are you aware of any class assignments requiring the use of the $N U C$ ?

$\square$ Yes

$\square$ No

If Yes, what type of course(s)?

11. How often do you estimate the $N U C$ is used by patrons per year? (choose one)

$\square$ Never

$\square$ to 5

$\square \quad 6$ to 20

$\square 20+$

$\square$ Do not know.

12. Have you considered withdrawing the NUC?

$\square$ Yes

$\square$ No 
NUC, Quo Vadis?

13. What are your reasons for not weeding the NUC? (answer all that apply)

$\square$ Still useful for cataloging or ILL, not all NUC content is in WorldCat.

$\square$ Still of use to researchers.

$\square$ It was an expensive and iconic work.

$\square$ There may be $N U C$ users we are unaware of.

$\square$ Public relations concerns / Patron backlash.

$\square$ The high cost of physical removal (labor, recycling, etc.)

$\square$ Difficulty in finding our set a new home.

$\square$ Other (please comment)

14. When was the last time you used the NUC?

$\square$ This year.

15 years ago.

$5+$ years ago.

Have never used.

15. If you could wave a magic wand and have the NUC disappear without a trace or a memory, would you?
$\square$ Yes
$\square$ No
$\square$ Indifferent

Comment

Libraries that withdrew the $N U C$.

16. Your primary responsibilities is:

$\square$ collection development

$\square$ cataloging.

$\square$ Other (please comment)

17. The approximate size of your institution's student FTE enrollment (choose one):

$\square$ FTE Under 6,000 FTE

6,000 to $10,000 \mathrm{FTE}$

10,000 to $20,000 \mathrm{FTE}$

more than $20,000 \mathrm{FTE}$

18. Size of your annual collections budget for fiscal year 2010/2011 (choose one):

$\square$ less than $\$ 500,000$

$\square \$ 500,000$ to $\$ 1$ million

$\square \quad \$ 1$ million to $\$ 3$ million

$\square \$ 3$ million to $\$ 5$ million

$\square$ more than $\$ 5$ million

19. Subjectively, how do you describe your library's space situation for the paper collection? (choose one)

$\square$ Adequate amount of shelf space for the foreseeable future.

$\square$ Still sufficient shelf space, but concerns for the future.

$\square$ Shelf space is a current concern.

$\square$ Shelves are nearing full.

20. What is your estimate of your library's annual annual monograph acquisitions in a language other than English? (choose one)

$\square$ under $5 \%$

$\square \quad 5$ to $10 \%$

ㅁ 10 to $20 \%$

ㅁ more than $20 \%$ 
NUC, Quo Vadis?

Do not know.

21. What is your estimate of the percentage of individual titles your library adds annually for imprints prior to 1956 ? (choose one)

$\square \quad 0 \quad 5$ percent.

$\square \quad 510$ percent.

$\square \quad 10$ to 25 percent.

$\square$ more than 25 percent.

$\square$ Do not know

22. When was the $N U C$ removed from the collection? (choose one)

$\square \quad 0$ to 5 years ago

$\square \quad 6$ to 10 years ago

$11+$ years ago

Do not know. Before my time here.

23. What was the $N U C^{\prime}$ 's fate? (answer all that apply)

$\square$ Recycled paper.

$\square$ Found a home in another library.

$\square$ Found a home with a private owner.

$\square$ Other (please comment)

24. What was the primary reason for weeding the NUC? (answer all that apply)

$\square \quad$ Need for space.

$\square \quad$ No longer used.

$\square$ Other (please comment)

25. Who was involved in making the decision to weed the $N U C$ ? (check all that apply)

$\square$ Librarians.

$\square \quad$ Teaching and research faculty.

$\square$ Consulted with other libraries.

$\square$ Other (please comment)

26. Since disposing of the $N U C$, how do you catalog older materials not found in WorldCat? (check all that apply)

$\square$ Original cataloging.

$\square$ Outsourced cataloging service.

$\square$ Add to backlog.

$\square$ Do not know.

Other (please comment)

27. Were there anticipated or unanticipated reactions, positive or negative, to withdrawing $N U C$ ? Comment:

28. Do you have any regrets after weeding the $N U C$ ?

$\square$ Yes

$\square \quad$ No

Comment:

29. Any other observations about removing the $N U C$ ? Please write us in the box below. Thanks!

\section{Thank you and Goodbye!}

Thanks for your time and information! Please click on [DONE] below. 